\title{
Virulence genotyping and antimicrobial resistance profiles of Yersinia enterocolitica isolated from meat and meat products in Egypt
}

\author{
G. A. Younis ${ }^{a}$ (D) R. M. Elkenany ${ }^{a *}$ (D) and H. A. Dowidar ${ }^{b}$ \\ aDepartment of Bacteriology, Mycology and Immunology, Faculty of Veterinary Medicine, Mansoura University, 35516, \\ Mansoura, Egypt \\ ${ }^{\mathrm{b}} \mathrm{Al}$-Azhar University, Mansoura, Egypt \\ *e-mail: dr_rashavet22@yahoo.com
}

Received: October 14, 2019 - Accepted: March 18, 2020 - Distributed: May 31, 2021

(With 7 figures)

\begin{abstract}
Pathogenic Yersinia enterocolitica (Y. enterocolitica) is one of the food-borne entero-pathogen responsible for yersiniosis in humans. The purpose of this research was to survey the prevalence, virulence-associated genes, and antimicrobial resistance of $Y$. enterocolitica isolated from meat and meat product samples in Egypt. Forty-one (5.9\%) out of 700- samples of chicken meat, beef, ground beef, and sausage were positive $Y$. enterocolitica with a high prevalence in chicken meat $(12 \%)$. Five virulence genes ( $a i l$, inv, yst $A, y s t B$, and $y a d A$ ) were characterized among $41 \mathrm{Y}$. enterocolitica isolates with variable frequencies. Among the strains tested, the $y s t B$ gene was detected with a high percentage (78.1\%), followed by inv gene (70.7\%), ail gene (14.6\%), ystA gene (12.2\%), and yadA gene (2.4\%). A high resistance rate was estimated to amoxicillin-clavulanic acid (100\%), followed by cefazolin (95\%), ampicillin (65.9\%), and doxycycline (51.2\%), whilst a high sensitivity rate was observed to gentamicin and ciprofloxacin $(97.6 \%$ each). Interestingly, the multidrug resistance was specified in the $70.7 \%$ of strains and showing 13 resistance patterns. Based on nucleotide sequence analysis of the $16 \mathrm{~s} r R N A$ gene, the phylogenetic tree showed the genetic relatedness amongst $Y$. enterocolitica isolates. These findings highlighted the emergence of virulent and multidrug-resistant pathogenic Y. entrocolitica in retailed meat and meat products in Egypt.
\end{abstract}

Keywords: Yersinia enterocolitica, meat and meat products, virulence genes, antimicrobial resistance, $16 s \mathrm{r} R A$ gene.

\section{Genotipagem de virulência e perfis de resistência antimicrobiana de Yersinia enterocolitica isolados de carne e derivados no Egito}

\section{Resumo}

A Yersinia enterocolitica patogênica ( $Y$. enterocolitica) é um dos enteropatógenos de origem alimentar responsáveis pela yersiniose no ser humano. $\mathrm{O}$ objetivo desta pesquisa foi avaliar a prevalência, genes associados à virulência e resistência antimicrobiana de $Y$. enterocolitica isolada de amostras de carne e produtos à base de carne no Egito. Quarenta e um (5,9\%) de 700 amostras de carne de frango, carne bovina, moída e linguiça foram $Y$. enterocolitica positivas, com alta prevalência em carne de frango (12\%). Cinco genes de virulência (ail, inv, ystA, ystB e yadA) foram caracterizados entre 41 isolados de $Y$. enterocolitica com frequências variáveis. Entre as cepas testadas, o gene $y s t B$ foi detectado com uma alta porcentagem (78,1\%), seguido pelo gene inv $(70,7 \%)$, ail genes $(14,6 \%)$, gene ystA $(12,2 \%)$ e gene yadA (2,4\%). Foi estimada uma alta taxa de resistência ao ácido amoxicilina-clavulânico (100\%), seguida de cefazolina (95\%), ampicilina $(65,9 \%)$ e doxiciclina $(51,2 \%)$, enquanto uma alta taxa de sensibilidade foi observada para gentamicina e ciprofloxacina $(97,6 \%$ cada). Curiosamente, a resistência a múltiplas drogas foi especificada em $70,7 \%$ das cepas e mostrando 13 padrões de resistência. Com base na análise da sequência nucleotídica do gene $r R N A$ $16 \mathrm{~s}$, a árvore filogenética mostrou a relação genética entre isolados de Y. enterocolitica. Esses achados destacaram o surgimento de $Y$. entrocolitica patogênica virulenta e multirresistente em carnes e produtos à base de carne no Egito.

Palavras-chave: Yersinia enterocolitica, carne e produtos à base de carne, genes de virulência, resistência antimicrobiana, gene $r R N A 16 \mathrm{~s}$.

\section{Introduction}

Yersinia genus belongs to the Enterobacteriaceae family and encompasses three well-recognized human pathogens which are Y. enterocolitica, Yersinia pseudotuberculosis, and Yersinia pestis (Carniel, 2006). Y. enterocolitica is one of the most important pathogens responsible for foodborne gastroenteritis (Yersiniosis) in Western and Northern Europe 
(EFSA, 2018). Other clinical syndromes associated with Y. enterocolitica are enterocolitis, mimicking appendicitis, acute mesenteric lymphadenitis, post-infectious arthritis, and systemic infections, so occasion fatal sepsis (Neubauer et al., 2001). Y. enterocolitica is often isolated from humans, a variety of animals, food and the environment (Falcão et al., 2006). Pigs are carriers of $Y$. enterocolitica without clinical signs in their oral cavity, on tongues, and then excrete these bacteria in their feces (Paixão et al., 2013).

The presence of virulence genes and virulence plasmids were applied for the estimation of pathogenic $Y$. enterocolitica strains (Platt-Samoraj et al., 2006; Peruzy et al., 2017). Virulence genes, ail, ystA, and $y s t B$ are located on the bacterial chromosome (Thong et al., 2018). The Ail protein is encoded by the ail gene and only occurs in pathogenic $Y$. enterocolitica, it contributes to bacterial adhesion to the host cell as well as strengthens resistance to the bactericidal effects of complement (Thoerner et al., 2003). Moreover, the yst gene, which encodes the thermostable enterotoxin Yst protein, advanced the invasion of the $Y$. enterocolitica into host cells (Atkinson and Williams, 2016). The ystA and $y s t B$ are produced by pathogenic and non-pathogenic Y. enterocolitica, respectively (Howard et al., 2006). The yadA gene is one of the most important virulence plasmids of $Y$. enterocolitica, its product is implicated in auto-agglutination, serum resistance, in addition to adhesion (Atkinson and Williams, 2016). Also, virF $(l c r F)$ codes transcriptional activators of the yop regulon (Cornelis et al., 1989).

The estimation of Yersinia species is commonly occurred by an examination of the biochemical profile. In contrast, biochemical identification is laborious and restricted, as biochemically atypical strains might be hard to assign to a species (Nanni et al., 1991). Thus, trials were applied to improve the capability to study this bacterium in samples through the development of sensitive and specific PCR assays for the recognition of Yersinia species. The $Y$. enterocolitica is popular reason in cases of food poisoning and is involved in a wide range of gastrointestinal diseases, the evolution of a PCR assay that could be employed to designate $Y$. enterocolitica positive sample to a particular bio-group has considerable implications for microbiological research, and epidemiological research (Havens et al., 2003). The sequence analysis of small subunit ribosomal RNA (16S rRNA) or the correlated genes (16S rDNA), then comparing the sequence with the other bacterium is more specialized analysis to appoint genus of bacterium (Woese, 1987; Schmidt and Relman, 1994). The sequence determinants have been simplified by the practice of PCR assay to produce the targets, then direct sequence analysis of the products, consequently terminate the requirement for cloning (Bottger, 1989).

Over several years, many antibiotics have been synthesized, resulting in satisfaction with the risk of bacterial resistance. Resistant of microorganisms to antimicrobial agents as a consequence of chromosomal changes or the interchange of genetic material via plasmids and transposons (Neu, 1992). Determination of drug resistance and the detection of virulence genes have influenced a clinical investigation (Li and Fanning, 2017). Y. enterocolitica was previously detailed to be extremely susceptible to many antimicrobial agents exclude penicillin, ampicillin, amoxicillin-clavulanic acid, and the first-generation cephalosporins (Bolton et al., 2013). Though, the high prevalence of drug-resistant $Y$. enterocolitica strains in food and the environment have been stated in recent years, because of excessive use of antibiotics in animal farms and antibiotic-resistance bacteria/gene transmission amongst dissimilar species (Ye et al., 2016).

To the best of our data, a limited investigation is available on the estimate of $Y$. enterocolitica isolated from meat and meat products in Egypt. Therefore, in such investigation, $Y$. enterocolitica isolated from meat and meat products were tested for their virulence genes, antibiotic susceptibility as well as $16 s r R A$ gene sequence analysis in Egypt.

\section{Material and Methods}

\subsection{Samples collection}

A total of 700 random representative samples of chicken meat, beef, ground beef, and sausage samples (175 samples, for each) were purchased from 100 different supermarkets and retail outlets in different localities at Dakahlia Governorate, Egypt, from October 2017 to April 2019. Each sample was weighed, marked clearly, put in a separate sterile plastic bag and kept in icebox during transportation to the laboratory. Each sample was estimated to bacteriological examination.

\subsection{Isolation and Identification of $Y$. enterocolitica}

A $25 \mathrm{~g}$ aliquot of each sample was put into sterile bags containing $225 \mathrm{~mL}$ of phosphate-buffered saline pH 7.6 added with $1 \%$ sorbitol and $0.15 \%$ bile salts and homogenized by bag mixer for $2 \mathrm{~min}$. These diluted samples were incubated at $25^{\circ} \mathrm{C}$ for $2-3 \mathrm{~d}$ in a shaker incubator. Subsequently, $0.5 \mathrm{~mL}$ of the enriched samples was mixed with $4.5 \mathrm{ml}$ of potassium hydroxide (KOH) $0.25 \%$ and inoculated onto Yersinia-selective agar (Cefsulodin-Irgasan-Novobiocin (CIN) [Oxoid, UK] agar) plates which then were incubated at $30{ }^{\circ} \mathrm{C}$ for 1-2 d. The suspected small colonies with a deep red center and sharp border surrounded by a clear colorless zone with the entire edge in the CIN agar plates were selected. Such characteristic colonies for Yersinia were biochemically confirmed by catalase, oxidase, triple sugar iron, and urease tests (Wang et al., 2009; Liang et al., 2012) $Y$. enterocolitica were oxidase and $\mathrm{H}_{2} \mathrm{~S}$-negative, catalase- and urease positive, glucose fermenter, and non-lactose-fermenter. Moreover, the determination of virulence plasmid of $Y$. enterocolitica was performed by auto-agglutination test and Congo red absorption by Congo red magnesium oxalate agar (Oxoid) (Mastrodonato et al., 2018) and were examined for its capability of biofilms production using the tube method (Hassan et al., 2011). 


\subsection{Molecular determination of $Y$. enterocolitica and virulence encoded genes}

PCR assays were completely performed to detect specific 16s rRNA gene for $Y$. enterocolitica, chromosomal-encoded virulence genes (ail, inv, yst $A$, and ystB) and plasmid-coded virulence genes ( $\mathrm{yadA})$. The extraction of bacterial genome DNA from purified suspected colonies was occurred by the conventional boiling method (Zeinali et al., 2015). The amplification of extracted of DNA was done in Applied Biosystem, 2720 Thermal Cycler (USA) in a total volume of $25 \mu \mathrm{L}$ consisted of $12.5 \mu \mathrm{L}$ of $2 \times$ PCR master mix (Promega, Madison, USA), $1 \mu \mathrm{L}$ of individual primer(Metabion, Germany), $4.5 \mu \mathrm{LPCR}$-grade water, and $6 \mu \mathrm{LDNA}$ template. The specific primers used and the PCR conditions were summarized in Table 1. The amplified PCR products were arranged on a 1.5\% agarose gel which was stained by $1 \%$ ethidium bromide and photo-documented under UV illumination. Y. enterocolitica (ATCC 9610) was used as a model of positive control.

\subsection{Sequencing of the 16s rRNA in Y. enterocolitica}

The purification of amplified product was formed from one representative strain by a QIAquick PCR product extraction kit (Qiagen, Valencia, CA) and was sequenced with Bigdye Terminator cycle sequencing ready reaction kit (Applied Biosystems, Foster City, CA) using an Applied Biosystems 3130 Genetic Analyzer (Hitachi, Tokyo, Japan) according to the instructions of the manufacturer.

\subsection{Sequence analysis}

The comparison of sequences of this strain was achieved with other strains on GenBank using BLAST 2.0 and PSI-BLAST research programs, (NCBI). A comparative analysis of sequences was made by the CLUSTAL W multiple sequence alignment program, version 1.83 of the MegAlign module of Lasergene DNAStar software Pairwise, which was intended by Thompson et al. (1994). The phylogenetic analyses were performed using maximum likelihood, neighbor-joining process, and maximum parsimony in MEGA6 (Tamura et al., 2013).

\subsection{Nucleotide accession number}

In this research, the nucleotide sequence of the Yersinia enterocolitica strain YEDH88, comprising the 16s rRNA gene was deposited in GenBank under accession no. MK910030.

\subsection{Antibiotic susceptibility testing}

Convinced $Y$. enterocolitica strains were examined for their sensitivity to eleven commercially available antibiotic disks (Oxoid, Ltd.) on Mueller-Hinton agar (Difco) by the standard disk diffusion method as stated by the referenced of the Clinical and Laboratory Standards Institute (CLSI, 2016). Taking into consideration their clinical usage in humans and veterinary medicine, the subsequent 11 antibiotic agents were selected: amoxicillin-clavulanic acid (AMC) $(30 \mu \mathrm{g})$; cefazolin $(30 \mu \mathrm{g})$; ampicillin $(10 \mu \mathrm{g})$; trimethoprim/ sulfamethoxazole (SXT) $(25 \mu \mathrm{g})$; doxycycline $(30 \mu \mathrm{g})$; cephalotin $(30 \mu \mathrm{g})$; kanamycin $(30 \mu \mathrm{g})$; chloramphenicol $(30 \mu \mathrm{g})$; ciprofloxacin $(5 \mu \mathrm{g})$; fosfomycin $(50 \mu \mathrm{g})$ and gentamicin $(10 \mu \mathrm{g})$. The diameter of the inhibition zone was measured and interpreted as resistant, intermediate, or susceptible according to the guidelines of the Clinical and Laboratory Standards Institute (CLSI, 2016). Usage of Escherichia coli ATCC 9610 as a reference strain was done.

\section{Results}

\subsection{Prevalence of $Y$. enterocolitica strains in meat and meat products}

Of the 700 samples, $5.9 \%$ (41) Y. enterocolitica strains were isolated from meat and meat product samples and confirmed by PCR assay (Figure 1). Regarding types of samples, $Y$. enterocolitica strains showed a high prevalence of $12 \%(21 / 175)$ in chicken meat, followed by $5.1 \%(9 / 175)$ ground beef, sausage, and $1.1 \%(2 / 175)$ beef.

\subsection{Determination of virulence genes in $Y$. enterocolitica strains}

$Y$. enterocolitica isolates were screened for the existence of chromosomal virulence genes (ail, inv, yst $A$, and $y s t B$ ) and plasmid virulence gene (yadA) (Figures 2-6). From all samples, the $y s t B$ gene was detected with a high percentage of $78.1 \%(32 / 41)$, followed by inv gene with

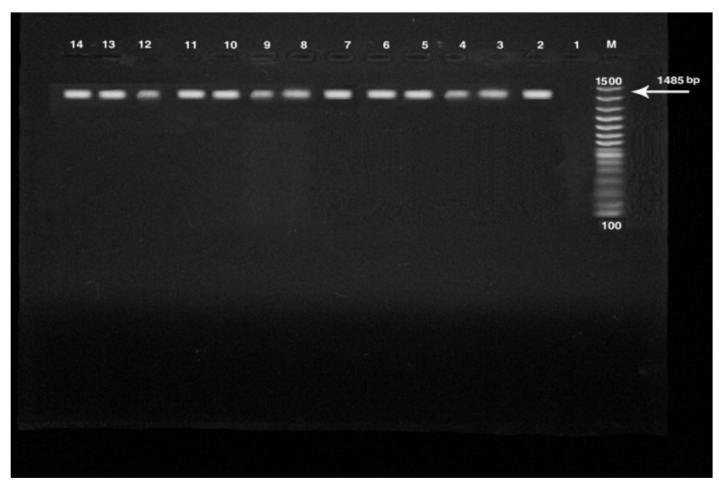

Figure 1. Prevalence of Yersinia enterocolitica strains l6s rRNA gene (1485bp). Lane M: 100 bp ladder; lane 1: negative control; lane 2: positive control Yersinia enterocolitica subsp. enterocolitica ATCC 9610; lanes 3-14: positive samples.

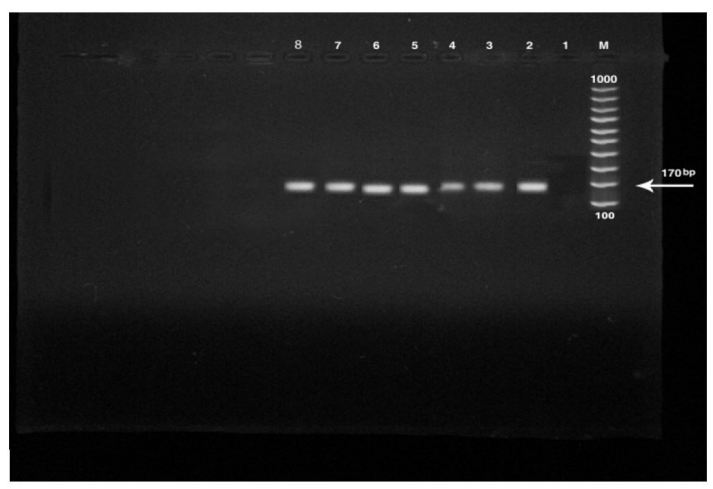

Figure 2. Prevalence of Yersinia enterocolitica virulence ail gene (170 bp). Lane M: 100 bp ladder; lane 1: negative control; lane 2: positive control Yersinia enterocolitica subsp. enterocolitica ATCC 9610; lanes 3-7: positive samples. 


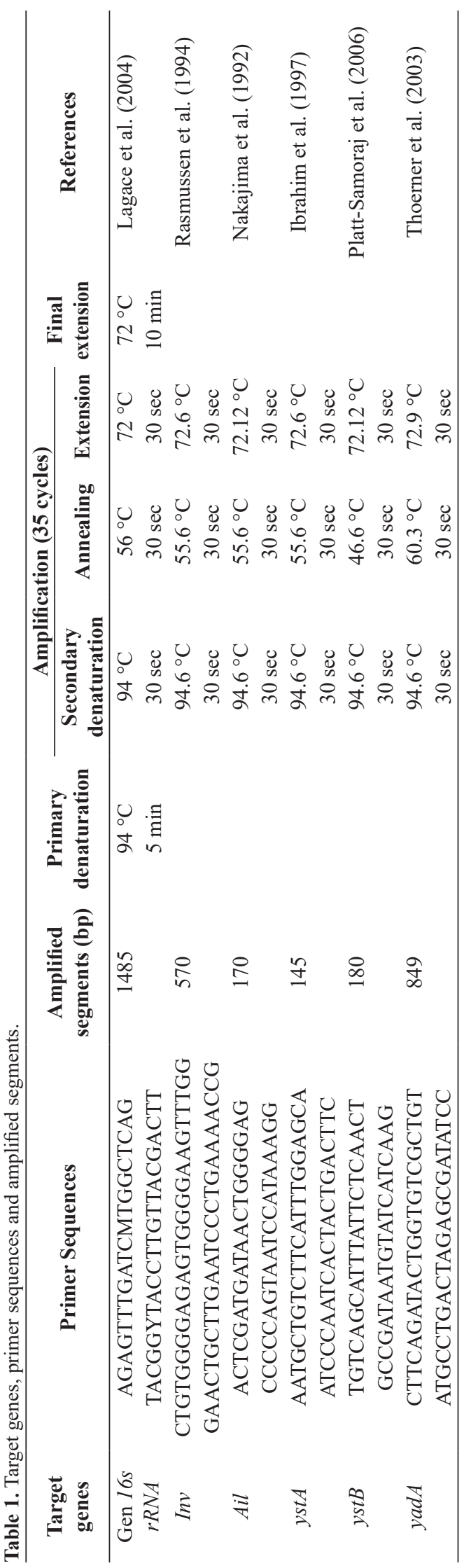




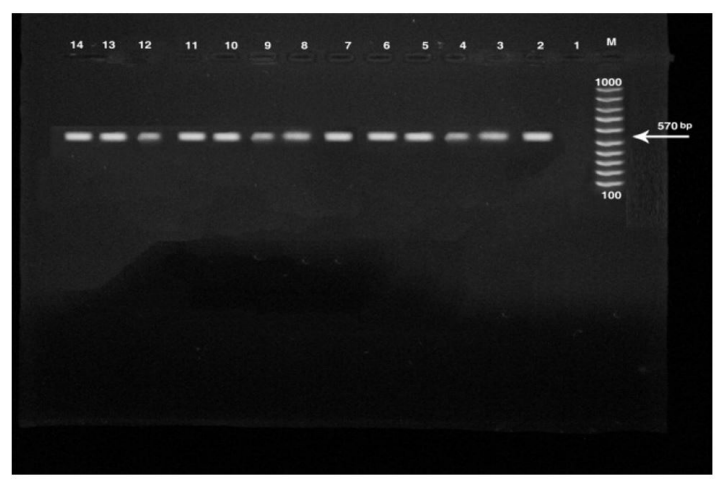

Figure 3. Prevalence of Yersinia enterocolitica virulence inv gene (570bp). Lane M: 100 bp ladder; lane 1: negative control; lane 2: positive control Yersinia enterocolitica subsp. enterocolitica ATCC 9610; lanes 3-14: positive samples.

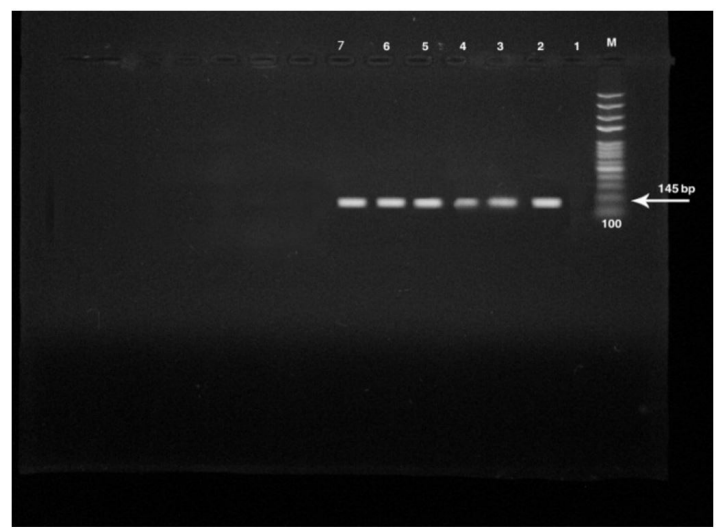

Figure 4. Prevalence of Yersinia enterocolitica virulence ystA gene (145 bp). Lane M: 100 bp ladder; lane 1: negative control; lane 2: positive control Yersinia enterocolitica subsp. enterocolitica ATCC 9610; lanes 3-6: positive samples.

70.7\% (29/41), ail gene $14.6 \%(6 / 41)$, ystA gene $12.2 \%$ $(5 / 41)$ and yadA gene 2.4\% (1/41).

Virulence genes of $Y$. enterocolitica strains were distributed as shown in Table 2. The chromosomal (ail, inv, $y s t A$, and $y s t B$ ) encoded virulent genes were demonstrated in the several categories of $Y$. enterocolitica strains in meat and meat products. Of note, plasmid ( $\mathrm{yadA}$ ) encoded virulence gene was determined only in one isolate (No. 1), obtained from ground beef. Twelve isolates from chicken meat, two isolates from beef, nine isolates from ground beef and sausage carried the gene $y s t B$. Ten isolates from chicken meat, two isolates from beef, nine isolates from ground beef, and eight from sausage had the inv gene. Two isolates from chicken meat and ground beef, one isolate from beef and sausage contain the ail gene.

\subsection{Identification of the sequence of the 16s rRNA gene in Y. enterocolitica strain}

Sequencing of the $16 \mathrm{~s} r R N A$ gene from one purified PCR product of one $Y$. enterocolitica strain YEDH88 isolated from ground beef was achieved. This $Y$. enterocolitica strain

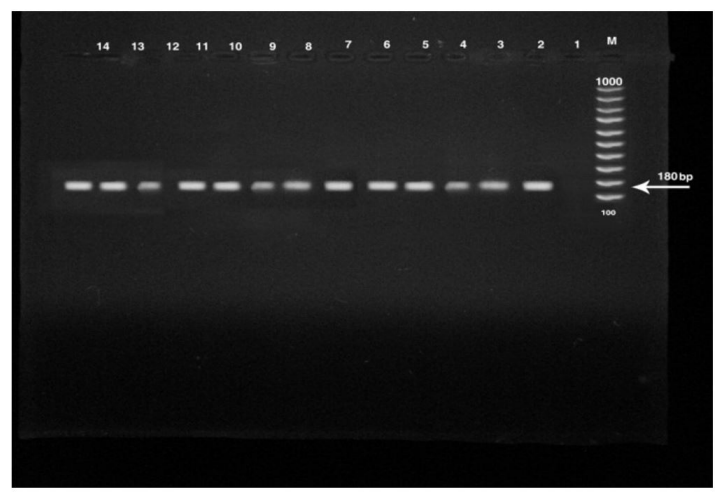

Figure 5. Prevalence of Yersinia enterocolitica virulence $y s t B$ gene (180bp). Lane M: 100 bp ladder; lane 1: negative control; lane 2: positive control Yersinia enterocolitica subsp. enterocolitica ATCC 9610; lanes 3-14: positive samples.

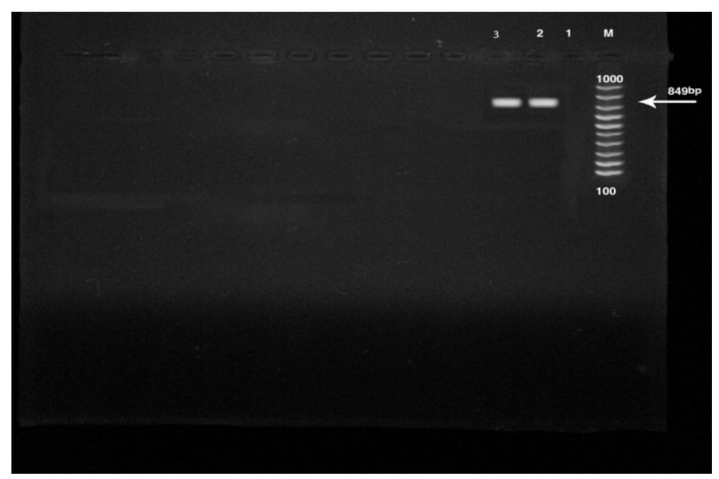

Figure 6. Prevalence of Yersinia enterocolitica virulence yadA gene ( $849 \mathrm{bp})$. Lane M: 100 bp ladder; lane 1: negative control; lane 2: positive control Yersinia enterocolitica subsp. enterocolitica ATCC 9610; lanes 3: positive sample.

YEDH88 was identical to several strains of $Y$. enterocolitica subsp. enterocolitica with 98.7-99.8\% similarity and then, the sequence was recorded in GenBank under the accession number MK910030. Furthermore, the phylogenetic tree based on nucleotide sequence analysis of the $16 \mathrm{~s} r R N A$ genes is indicating the genetic relationship among $26 Y$. enterocolitica strains found in different countries (Table 3) (Figure 7).

\subsection{Results of antibiotic susceptibility testing}

The phenotypic resistance of $Y$. enterocolitica isolates using the disk diffusion assay displayed a high resistance to AMC (100\%), followed by cefazolin (95\%), ampicillin (65.9\%), and doxycycline (51.2\%). On the other hand, the highest susceptibility rate to gentamicin and ciprofloxacin $(97.6 \%$ each) was observed, followed by SXT and chloramphenicol ( $92.7 \%$ each), kanamycin and cephalotin (85.4\% each), and fosfomycin $(70.7 \%)$ (Table 4). Furthermore, thirteen resistance patterns were identified in the examined isolates (Table 2). Among 
Table 2. Source, resistance pattern and virulence genes of $Y$. enterocolitica isolates.

\begin{tabular}{|c|c|c|c|c|c|c|c|c|}
\hline \multirow{2}{*}{$\begin{array}{c}\text { Strain } \\
\text { No. }\end{array}$} & \multirow{2}{*}{ Serotype } & \multirow{2}{*}{ Source } & \multirow{2}{*}{ Resistance pattern } & \multicolumn{5}{|c|}{ Virulence gene } \\
\hline & & & & Ail & inv & yst $A$ & Ystb & yadA \\
\hline 1 & Yenterocolitica & Ground beef & AMC/CFZ/AM/DOX/SXT/KF/C & + & + & + & + & + \\
\hline 2 & Y.enterocolitica & Ground beef & $\mathrm{AMC} / \mathrm{CFZ} / \mathrm{AM} / \mathrm{FOS} / \mathrm{KF} / \mathrm{K}$ & + & + & - & + & - \\
\hline 3 & Y.enterocolitica & Ground beef & $\mathrm{AMC} / \mathrm{CFZ} / \mathrm{AM} / \mathrm{FOS} / \mathrm{DOX} / \mathrm{KF} / \mathrm{C}$ & + & + & + & - & - \\
\hline 4 & Y.enterocolitica & Beef & AMC/CFZ/AM/FOS/DOX & - & + & - & + & - \\
\hline 5 & Y.enterocolitica & sausage & $\mathrm{AMC} / \mathrm{CFZ} / \mathrm{AM} / \mathrm{FOS} / \mathrm{DOX} /$ & + & + & + & + & - \\
\hline 6 & Y.enterocolitica & Sausage & $\mathrm{AMC} / \mathrm{CFZ} / \mathrm{AM} / \mathrm{DOX}$ & - & + & - & + & - \\
\hline 7 & Y.enterocolitica & Chicken meat & AMC/CFZ/AM/DOX/SXT & - & + & - & + & - \\
\hline 8 & Y.enterocolitica & Chicken meat & AMC/CFZ/AM/DOX/SXT & - & + & - & + & - \\
\hline 9 & Y.enterocolitica & Chicken meat & $\mathrm{AMC} / \mathrm{CFZ} / \mathrm{AM} / \mathrm{DOX}$ & - & + & - & + & - \\
\hline 10 & Y.enterocolitica & Chicken meat & AMC/CFZ/AM/DOX/FOS & - & + & - & + & - \\
\hline 11 & Y.enterocolitica & Chicken meat & AMC/CFZ/AM/DOX & - & + & - & + & - \\
\hline 12 & Yenterocolitica & Ground beef & AMC CFZ/AM/FOS & - & + & - & + & - \\
\hline 13 & Yenterocolitica & Ground beef & $\mathrm{AMC} / \mathrm{CFZ} / \mathrm{AM} / \mathrm{DOX}$ & - & + & - & + & - \\
\hline 14 & Yenterocolitica & Beef & $\mathrm{AMC} / \mathrm{CFZ} / \mathrm{AM} / \mathrm{DOX}$ & - & + & - & + & - \\
\hline 15 & Yenterocolitica & Sausage & $\mathrm{AMC} / \mathrm{AM} / \mathrm{DOX} / \mathrm{K}$ & - & + & - & - & - \\
\hline 16 & Yenterocolitica & Sausage & $\mathrm{AMC} / \mathrm{CFZ} / \mathrm{AM}$ & - & + & - & - & - \\
\hline 17 & Y.enterocolitica & Chicken meat & $\mathrm{AMC} / \mathrm{CFZ} / \mathrm{AM}$ & - & - & - & + & - \\
\hline 18 & Y.enterocolitica & Chicken meat & AMC / CFZ/AM/FOS & + & + & + & + & - \\
\hline 19 & Y.enterocolitica & Sausage & AMC /AM/DOX & - & + & - & - & - \\
\hline 20 & Yenterocolitica & Chicken meat & $\mathrm{AMC} / \mathrm{CFZ} / \mathrm{AM} / \mathrm{DOX}$ & - & + & - & - & - \\
\hline 21 & Y.enterocolitica & Ground beef & $\mathrm{AMC} / \mathrm{CFZ} / \mathrm{AM} / \mathrm{DOX}$ & - & - & - & + & - \\
\hline 22 & Y.enterocolitica & Chicken meat & AMC / CFZ/AM/DOX & - & - & - & + & - \\
\hline 23 & Y.enterocolitica & Sausage & AMC / CFZ/AM/DOX & - & + & - & - & - \\
\hline 24 & Y.enterocolitica & Sausage & AMC / CFZ/AM/DOX & - & + & - & - & - \\
\hline 25 & Y.enterocolitica & Chicken meat & $\mathrm{AMC} / \mathrm{CFZ} / \mathrm{AM}$ & - & + & - & + & - \\
\hline 26 & Yenterocolitica & Chicken meat & $\mathrm{AMC} / \mathrm{CFZ} / \mathrm{AM}$ & - & + & - & - & - \\
\hline 27 & Y.enterocolitica & Ground beef & $\mathrm{AMC} / \mathrm{CFZ} / \mathrm{AM}$ & - & + & - & + & - \\
\hline 28 & Y.enterocolitica & Sausage & AMC / CFZ & - & - & - & + & - \\
\hline 29 & Y.enterocolitica & Chicken meat & AMC CFZ/FOS/DOX & + & + & + & - & - \\
\hline 30 & Yenterocolitica & Chicken meat & $\mathrm{AMC} / \mathrm{CFZ}$ & - & - & - & + & - \\
\hline 31 & Y.enterocolitica & Ground beef & $\mathrm{AMC} / \mathrm{CFZ}$ & - & - & - & + & - \\
\hline 32 & Yenterocolitica & Chicken meat & $\mathrm{AMC} / \mathrm{CFZ}$ & - & - & - & + & - \\
\hline 33 & Y.enterocolitica & Sausage & AMC / CFZ/DOX & - & + & - & + & - \\
\hline 34 & Y.enterocolitica & Ground beef & $\mathrm{AMC} / \mathrm{CFZ}$ & - & + & - & + & - \\
\hline 35 & Y.enterocolitica & Chicken meat & $\mathrm{AMC} / \mathrm{CFZ}$ & - & - & - & + & - \\
\hline 36 & Y.enterocolitica & Chicken meat & $\mathrm{AMC} / \mathrm{CFZ}$ & - & - & - & + & - \\
\hline 37 & Y.enterocolitica & Chicken meat & AMC / CFZ & - & - & - & + & - \\
\hline 38 & Y.enterocolitica & Chicken meat & $\mathrm{AMC} / \mathrm{CFZ}$ & - & + & - & + & - \\
\hline 39 & Yenterocolitica & Chicken meat & $\mathrm{AMC} / \mathrm{CFZ}$ & - & + & - & + & - \\
\hline 40 & Y.enterocolitica & Chicken meat & AMC / CFZ & - & - & - & + & - \\
\hline 41 & Y.enterocolitica & Chicken meat & $\mathrm{AMC} / \mathrm{CFZ}$ & - & - & - & + & - \\
\hline $\begin{array}{c}\text { Total } \\
\%\end{array}$ & 41 & 41 & 41(100) & $6(14.6)$ & $29(70.7)$ & $5(12.2)$ & $32(78.1)$ & $1(2.4)$ \\
\hline
\end{tabular}

AMC: amoxicillin-clavulanicacid; CFZ: cefazolin; AM: Ampicillin; SXT: Sulphamethoxazol-Trimethoprim; DOX: doxycyclin; KF: Cephalotin; K: Kanamycin; C: Chloramphenicol; FOS: fosfomycin.

these resistance patterns, the most common pattern was AMC/CFZ represented by $12(29.3 \%)$ strains followed by AMC/CFZ/AM/DOX displayed by 10 (24.3\%) strains. Remarkably, multidrug resistance (MDR) to more than two antimicrobial classes was demonstrated in 29 out of $41(70.7 \%)$ strains to show 13 resistance patterns. Of note, the presence of virulence determinants (ail, inv, yst A, ystB, and $y a d A$ ) in different $Y$. enterocolitica strains recovered from meat and meat product samples showed different antimicrobial resistance patterns as illustrated in Table 2. The detailed analysis exhibited relations of resistance phenotypes with potential virulence genes. 
Table 3. Detailed information of $16 \mathrm{~s} r R N A$ gene sequence of Yersinia enterocolitica used in this study with identity $\%$ of other strains in other countries.

\begin{tabular}{|c|c|c|c|c|c|}
\hline $\begin{array}{l}\text { Isolate } \\
\text { number }\end{array}$ & $\begin{array}{c}\text { Accession } \\
\text { number }\end{array}$ & Country & Year & Isolation source & $\begin{array}{c}\text { Identity } \\
\text { with strain } \\
\text { in this } \\
\text { study }\end{array}$ \\
\hline $2516-87$ & CP009838 & USA & 2015 & unknown & $99.5 \%$ \\
\hline 8081 & СР009846.1 & Russia & 1993 & Fatal septicemia & $99.0 \%$ \\
\hline WA & СР009367.1 & USA & 2015 & Homo sapiens & $98.7 \%$ \\
\hline FC1820 & MH174080.1 & China & 2018 & Waste & $99.3 \%$ \\
\hline FE80313 & HE803739.1 & Finland & 2012 & human faeces & $99.6 \%$ \\
\hline FE81536 & HE803738.1 & Finland & 2012 & Humanfaeces & $99.7 \%$ \\
\hline FE80919 & HE803741.1 & Finland & 2012 & Humanfaeces & $99.6 \%$ \\
\hline CVUAS & HQ222845.1 & Germany & 2012 & Salmo trutta & $99.6 \%$ \\
\hline DSM 13030 & NR_116786.1 & Finland & 2019 & unknown & $99.5 \%$ \\
\hline B-4-3 & JF922124.1 & China & 2011 & bamboo shoot spoilage & $99.7 \%$ \\
\hline Arma5a-a & KM888075.1 & Finland & 2014 & modified atmosphere-packaked broiler & $99.5 \%$ \\
\hline KM1 & EU523225.1 & China & 2008 & refrigerator of a meat factory & $99.4 \%$ \\
\hline FE81198 & HE803743.1 & Finland & 2012 & human faeces & $99.4 \%$ \\
\hline FE81535 & HE803744.1 & Finland & 2012 & human faeces & $99.4 \%$ \\
\hline WSTY 161ON & KM888073.1 & Finland & 2014 & wild boar tonsils & $99.5 \%$ \\
\hline FYE155 & KM888020.1 & Finland & 2014 & vole, intestine & $99.5 \%$ \\
\hline FE81651 & HE803746.1 & Finland & 2012 & human faeces & $99.4 \%$ \\
\hline WSTY 3D2 & KM888074.1 & Finland & 2014 & wild boar tonsils & $99.7 \%$ \\
\hline T51A14.1 & KM888064.1 & Finland & 2014 & vole, tongue & $99.8 \%$ \\
\hline PUFSTb04 & KT266804.1 & India & 2015 & beef meat & $99.5 \%$ \\
\hline HYE9180 & KM888038.1 & Finland & 2014 & human feces & $99.7 \%$ \\
\hline FC1790 & MH177866.1 & China & 2018 & Waste & $99.5 \%$ \\
\hline FC1783 & MH174076.1 & China & 2018 & Waste & $99.5 \%$ \\
\hline NBRC 10569 & AB682267.1 & Japan & 2012 & unknown & $98.7 \%$ \\
\hline ATCC 9610 & NR_116785.1 & USA & 2014 & unknown & $98.7 \%$ \\
\hline FE80890 & HE803740.1 & Finland & 2012 & human faeces & $99.6 \%$ \\
\hline
\end{tabular}

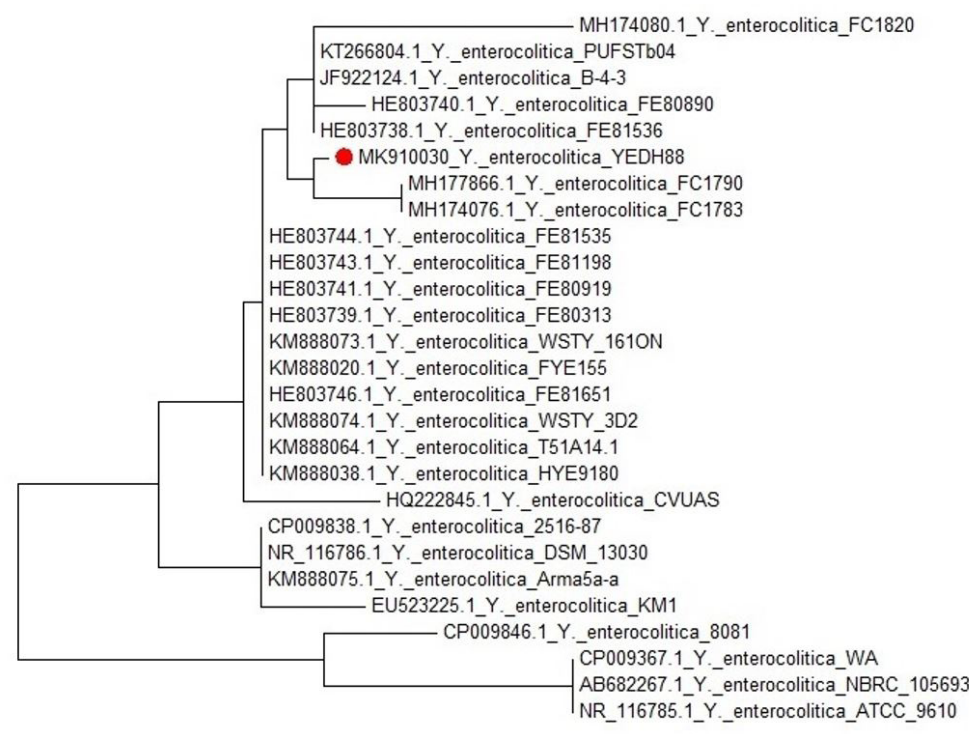

$$
\longmapsto
$$

Figure 7. Phylogenetic tree showing the genetic relatedness among Yersinia enterocolitica strains based on nucleotide sequence analysis of the $16 \mathrm{~s} r \mathrm{r} A$ gene. 
Table 4. Results of antimicrobial resistance susceptibility test

\begin{tabular}{|c|c|c|c|}
\hline \multirow{2}{*}{ Antibiotics } & Sensitive & Intermediate & Resistant \\
\hline & No. $(\%)$ & No. $(\%)$ & No. $(\%)$ \\
\hline Amoxicillin-clavulanicacid (AMC) & 0 & - & $41(100)$ \\
\hline Cefazolin (CFZ) & 0 & $2(4.8)$ & $39(95)$ \\
\hline Ampicillin (AM) & 0 & $14(34)$ & $27(65.9)$ \\
\hline Trimethoprim/sulfamethoxazole (SXT) & $38(92.7)$ & 0 & $3(7.3)$ \\
\hline Doxycyclin (DOX) & $10(24.4)$ & $10(24.4)$ & $21(51.2)$ \\
\hline Cephalotin (KF) & $35(85.4)$ & $3(7.3)$ & $3(7.3)$ \\
\hline Kanamycin (K) & $35(85.4)$ & $4(9.8)$ & $2(4.8)$ \\
\hline Chloramphenicol (C) & $38(92.7)$ & $2(4.8)$ & $2(4.8)$ \\
\hline Ciprofloxacin (CIP) & $40(97.6)$ & $1(2.4)$ & 0 \\
\hline Fosfomycin(FOS) & $29(70.7)$ & $4(9.8)$ & $8(19.5)$ \\
\hline Gentamicin $(\mathrm{G})$ & $40(97.6)$ & $1(2.4)$ & 0 \\
\hline
\end{tabular}

\section{Discussion}

$Y$. enterocolitica is one of the most common Gramnegative bacteria causing food poisoning, widespread in The environment, water, meats, and dairy products. Meat and meat products had been suggested as the main source of $Y$. enterocolitica for humans. In the United States and Canada, the high incidence of $Y$. enterocolitica was reported, even though this might be a result of the improvement of investigation and detection methods (Wesley et al., 2008). In this work, $Y$. enterocolitica overall prevalence was $5.9 \%$ in the meat and meat products. $Y$. enterocolitica prevalence in chicken meat $(12 \%)$ was slightly lesser than previous investigations: $16.7 \%$ in Turkey (Ozdemir and Arslan, 2015), 21.6\% in Iran (Dallal et al., 2010), $32.5 \%$ in Italy (Bonardi et al., 2010), and 55\% in Spain (Capita et al., 2002).

Moreover, the prevalence in ground beef $(5.1 \%)$ was consistent with Ozdemir and Arslan (2015), while this is lower than those detected by other authors (Sirıken, 2004). Also, the occurrence of $Y$. enterocolitica in beef $(1.1 \%)$ was compatible with previous studies (Dzomir, 2006), whereas it is lower than that reported in previous investigations as $27.9 \%$ in Turkey (Sirıken, 2004) and 5.5\% in Poland (Zadernowska and Chajęcka-Wierzchowska, 2016). Furthermore, the low frequency (5.1\%) of sausage contamination found is expected and following other reports (Ramirez et al., 2000) since it is a cooked and vacuum-packed product. It is well known that the risk of contamination is difficult to be eliminated in this type of product (Logue et al.. 1996). The contamination of meat and other meat products with bacteria from a slaughterhouse as well as from many equipments during processing, workers, air, and water could have occurred (Ray, 2004). In this study, chicken meat had the highest prevalence of $Y$. enterocolitica due to slaughter the poultry outside the slaughterhouse under unhygienic condition, also high levels of bacterial contamination occur especially during defeathering and water chilling. further, elevate the contamination levels during evisceration of the carcasses, washing, and processing due to contamination by workers
(Pieniz et al., 2019). On the other hand, the beef has the lowest percentage of isolates where the slaughter is done in a slaughterhouse of Mansoura city at Dakahlia Governorate, Egypt, showed lower contamination due to absence of section to slaughter pigs which are the carrier of $Y$. enterocolitica and excrete this bacterium in their feces (Paixão et al., 2013).

The key role in the $Y$. enterocolitica pathogenicity is the virulence genes (chromosome and plasmid) (Zheng et al., 2008). In the current research, the presence of chromosomal virulence genes (ail, inv, ystA, and ystB) and plasmid virulence genes (yadA) in Y. enterocolitica was occurred by PCR assay. The high occurrence of the $y s t B$ $(78.1 \%)$ and $i n v(70.7 \%)$ gene in the examined strains was detected. In accordance, Bhagat and Virdi (2007) found a high prevalence of inv (100\%) and ystB (79\%) genes in pathogenic isolates of $Y$. enterocolitica. In contrast, Kot et al. (2007) determined the low occurrence of inv (13.75\%) and $y s t B(4.35 \%)$ genes. Also, Ozdemir and Arslan (2015) recorded $y s t B$ in $20 \%$ of the isolates. Furthermore, the low percentage of other examined genes (ail, 14.6\% and $y s t A, 12.2 \%$ ) detected by this investigation. There was a lot of study that had a low or negative incidence of such virulence genes (ail and ystA) in pathogenic strains of $Y$. enterocolitica isolated from meat and other meat products (Falcão et al., 2006; Kot et al., 2007; Bhagat and Virdi, 2007; Ozdemir and Arslan, 2015). On the other hand, previous reports have a high prevalence of such virulence genes isolated from humans (Zheng et al., 2008; Frazão and Falcão, 2015). Besides, The yadA gene was identified in $2.4 \%$ of $Y$. enterocolitica strains in this research, while Tadesse et al. (2013) detected yadA gene in $12.8 \%$ of $Y$. enterocolitica strains isolated from porcine. There was no detection of the yadA gene in any samples isolates from chicken meat (Shabana et al., 2015).

Generally, pathogenic strains should have whole virulence genes (ail, inv, ystA, and yadA) such virulence genes were perhaps cooperating to cause a public health hazard (Zheng et al., 2008). However, in this work, only one isolate containing all tested virulence genes. A lot of 
the examined isolates in this research were positive for $y s t B$ and inv. On the other hand, other isolates were positive for only some of them, which could still be representative of public health hazards.

In contrast to methods of identifying bacteria using the phenotype, the genetic-based approach stands out for its consistency. The small subunit ribosomal RNA (16S rRNA), highly preserved and seldom variable within species, is one desirable candidate and is becoming a principal method for phylogeny study and species classification (Woese, 1987). Therefore, in this study, DNA sequence analysis of the $16 \mathrm{~s} r R N A$ gene of $Y$. enterocolitica isolate YEDH88 showed the genetic relatedness amongst $26 Y$. enterocolitica strains isolated from many countries as shown in the phylogenetic tree (Figure 7). Similar $16 s r R N A$ genes were previously specified in $Y$. enterocolitica as $Y$. enterocolitica T51A14.1 (KM888064.1) (Murros et al., 2016), Y. enterocolitica FE81536 (HE803738.1) (Sihvonen et al., 2012), Y. enterocolitica DSM 13030 (NR_116786.1) (Murros-Kontiainen et al., 2011) Y. enterocolitica FE81198 (HE803743.1) (Wortberg et al., 2012), Y. enterocolitica 2516-87 (CP009838.1) (Johnson et al., 2015).

Antibiotic resistance in pathogenic strains has been increasingly developed around the world in particular $Y$. enterocolitica (Ozdemir and Arslan, 2015). In this study, assay results from the antimicrobial sensitivity of $Y$. enterocolitica isolates provided high resistance to AMC followed by cefazolin, ampicillin, and doxycycline that were frequently reported (Bucher et al., 2008; FredrikssonAhomaa et al., 2010; Frazão et al., 2017). Such high resistance to AMC and ampicillin is due to the wide distribution of $\beta$-lactamases amongst $Y$. enterocolitica isolates (Fredriksson-Ahomaa et al., 2011). In contrast, the sensitivity of $Y$. enterocolitica to gentamicin, ciprofloxacin, SXT, chloramphenicol, kanamycin, and cephalotin was noticed in previous studies (Hadef et al., 2015; Frazão et al., 2017). Gentamicin and ciprofloxacin, the most clinically important antimicrobial, has been used very successfully in $Y$. enterocolitica osteomyelitis and septic arthritis (Carniel, 2006).

Interestingly, MDR pathogenic bacteria cause stiffness in the treatment of diseases affecting humans and animals and strains MDR of $Y$. enterocolitica were associated with the rise of the the morbidity, compared to the susceptible bacterium (Drozdov et al., 1992; Jean and Hsueh, 2011). Unfortunately, the results obtained in this research detected MDR against more than two antibiotics in $70.7 \%$ of isolates with 13 resistance patterns. However, there is little studies on the multidrug-resistant strains of $Y$. enterocolitica in meat and meat products in Egypt compared to other countries. Similar results in MDR $Y$. enterocolitica isolates were observed by many investigators (Bonardi et al., 2010; Thong et al., 2018). Younis et al. (2019) identified a low prevalence of MDR Y. enterocolitica isolates (23.33\%) from retail and processed meat in Egypt, while Ye et al. (2015) and Peng et al. (2018) demonstrated the high occurrence of MDR Y. enterocolitica strains (94.3\%, $92.3 \%$ ) in China, respectively. There are many reasons for the elevation of percentages of multidrug-resistant pathogenic bacterium including the illegal and inaccurate prescription of antibiotics, the long term use and even abuse of feed antibiotics (Dehkordi et al., 2014). While the global use of antibiotics in modern animal husbandry plays an important role in improving the prevention and control of animal diseases, the elevation of animal growth and high feed utilization rate, frequent use of veterinary antibiotics much more than the essential treatment of animal disease, and most of these antibiotics are used to improve the feed conversion and feed additives (Tsubakishita et al., 2010; Silva et al., 2011). Elevation of the microbial resistance problem and expectations for future use of antimicrobial drugs remains uncertain. Consequently, measures must be taken to reduce this problem, for example, to control the antibiotics used, to develop the research to better understand the genetic mechanisms of resistance, and to continue studies to improve new drugs. The ultimate goal is to provide the patient with appropriate and effective antimicrobial drugs (Höfling et al., 2010). Whatever, diversity in the use of many antibiotics in the treatment of humans and animals causes elevation of the microbial resistant bacterium to the human beings. The transmission of antibiotic-resistant bacteria to humans may be caused by the means of food, so the antimicrobial resistance of isolates in human and animal foods should be monitored continuously to avoid public health hazards (McDermott et al., 2002).

Generally, the acquirement of the antimicrobial resistance in the bacteria influences their virulence according to two alternative ways; elevated resistance is followed by elevated virulence (a positive effect) or raising antimicrobial resistance decreases a bacterium virulence (seemingly negative effect) (Beceiro et al., 2013). The presence of virulence determinants (ail, inv, ystA, ystB, and yadA) in different $Y$. enterocolitica isolates displayed various antimicrobial resistance patterns in this investigation. This research verified the dissemination of antimicrobial resistance patterns and virulence factors in the examined isolates. These results are important concerning public health and had been formerly reported (Sacchini et al., 2018). The antimicrobial resistance of bacterium is regularly developing and horizontal gene transmission by plasmids plays the main role (Rozwandowicz et al., 2018).

\section{Conclusion}

Meat and meat products might be a source of virulent and multi-drug resistant strains of $Y$. enterocolitica that might have a potential public-health hazard in Egypt. Accordingly, strict hygienic measures should be applied to minimize $Y$. enterocolitica contamination in meat and meat products.

\section{References}

ATKINSON, S. and WILLIAMS, P., 2016. Yersinia virulence factors: a sophisticated arsenal for combating host defences. F1000Res, vol. 5, pp. F1000. PMid:27347390. 
BECEIRO, A., TOMÁS, M. and BOU, G., 2013. Antimicrobial resistance and virulence: a successful or deleterious association in the bacterial world? Clinical Microbiology Reviews, vol. 26, no. 2, pp. 185-230. http://dx.doi.org/10.1128/CMR.00059-12. PMid:23554414

BHAGAT, N. and VIRDI, J.S., 2007. Distribution of virulenceassociated genes in Yersinia enterocoliticabiovar 1A correlates with clonal groups and not the source of isolation. FEMS Microbiology Letters, vol. 266, no. 2, pp. 177-183. http://dx.doi. org/10.1111/j.1574-6968.2006.00524.x. PMid:17233728.

BOLTON, D.J., IVORY, C. and MCDOWELL, D., 2013. A small study of Yersinia enterocolitica in pigs from birth to carcass and characterisation of porcine and human strains. Food Control, vol. 33, no. 2, pp. 521-524. http://dx.doi.org/10.1016/j. foodcont.2013.03.039.

BONARDI, S., PARIS, A., BASSI, L., SALMI, F., BACCI, C., RIBOLDI, E., BONI, E., D'INCAU, M., TAGLIABUE, S. and BRINDANI, F., 2010. Detection, semiquantitative enumeration, antimicrobial susceptibility of Yersinia enterocolitica in pork and chicken meats in Italy. Journal of Food Protection, vol. 73, no. 10, pp. 1785-1792. http://dx.doi.org/10.4315/0362-028X-73.10.1785. PMid:21067665.

BÖTTGER, E.C., 1989. Rapid determination of bacterial ribosomal sequences by direct sequencing of enzymatically amplified DNA. FEMS Microbiology Letters, vol. 65, no. 1-2, pp. 171-176. http:// dx.doi.org/10.1111/j.1574-6968.1989.tb03617.x. PMid:2482222.

BUCHER, M.C., MEYER, C., GRÖTZBACH, B., WACHECK, S., STOLLE, A. and FREDRIKSSON-AHOMAA, M., 2008. Epidemiological data on pathogenic Yersinia enterocolitica in Southern Germany during 2000-2006. Foodborne Pathogens and Disease, vol. 5, no. 3, pp. 273-280. http://dx.doi.org/10.1089/ fpd.2007.0076. PMid:18564908.

CAPITA, R., ALONSO-CALLEJA, C., PRIETO, M., GARCÍAFERNÁNDEZ, M.C. and MORENO, B., 2002. Incidence and pathogeniticity of Yersinia spp. isolates from poultry in Spain. Food Microbiology, vol. 19, no. 4, pp. 295-301. http://dx.doi. org/10.1006/fmic.2002.0492.

CARNIEL, E., 2006. Y. enterocolitica and Y. pseudotuberculosis. In: M. DWORKIN, S. FALKOW, E. ROSENBERG, K.H. SCHLEIFER and E. STACKEBRANDT, eds. The prokaryotes. New York: Springer, vol. 6, pp. 270-398. http://dx.doi.org/10.1007/0387-30746-X 13

CLINICALAND LABORATORY STANDARDS INSTITUTE CLSI, 2016. Performance standards for antimicrobial susceptibility testing. 26th ed. Wayne: CLSI.

CORNELIS, G., SLUITERS, C., DE ROUVROIT, C.L. and MICHIELS, T., 1989. Homology between $\operatorname{VirF}$, the transcriptional activator of the Yersinia virulence regulon, and AraC, the Escherichia coli arabinose operon regulator. Journal of Bacteriology, vol. 171, no. 1, pp. 254-262. http://dx.doi.org/10.1128/JB.171.1.254262.1989. PMid:2644192.

DALLAL, M.M., DOYLE, M.P., REZADEHBASHI, M., DABIRI, H., SANAEI, M., MODARRESI, S., BAKHTIARI, R., SHARIFIY, K., TAREMI, M., ZALI, M.R. and SHARIFI-YAZDI, M.K., 2010. Prevalence and antimicrobial resistance profiles of Salmonella serotypes, Campylobacter and Yersinia spp. isolated from retail chicken and beef, Tehran, Iran. Food Control, vol. 121, no. 4, pp. 388-392. http://dx.doi.org/10.1016/j.foodcont.2009.06.001.

DEHKORDI, F.S., YAZDANI, F., MOZAFARI, J. and VALIZADEH, Y., 2014. Virulence factors, serogroups and antimicrobial resistance properties of Escherichia coli strains in fermented dairy products. BMC Research Notes, vol. 7, no. 217, pp. 217. http://dx.doi. org/10.1186/1756-0500-7-217. PMid:24708594

DROZDOV, A.V., BELOKUROVA, T.V., IL'INA, T.S., DZIUBAK, V.F. and DOMARADSKIII, I.V., 1992. A new R-plasmid from Yersinia pseudotuberculosis. Molekuliarnaia Genetika, Mikrobiologiia $i$ Virusologiia, vol. 5, no. 6, pp. 31-32. PMid:1454082.

DZOMIR, A.Z.M., 2006 [viewed 30 July 2020]. Isolation, identification and characterization of Yersinia spp. from meat and meat products [online]. Malaysia: School of Graduate Studies, Universiti Putra Malaysia. Thesis in Philosophy. Available from: http://psasir.upm.edu.my/id/eprint/6712/1/FSTM_2005_3(1-24).pdf

EUROPEAN FOOD SAFETY AUTHORITY - EFSA, 2018. The european union summary report on trends and sources of zoonoses, zoonotic agents and food-borne outbreaks in 2010. EFSA Journal, vol. 16, no. 12, pp. 5500.

FALCÃO, J.P., FALCÃO, D.P., PITONDO-SILVA, A., MALASPINA, A.C. and BROCCHI, M., 2006. Molecular typing and virulence markers of Yersinia enterocolitica strains from human, animal and food origins isolated between 1968 and 2000 in Brazil. Journal of Medical Microbiology, vol. 55, no. 11, pp. 1539-1548. http:// dx.doi.org/10.1099/jmm.0.46733-0. PMid:17030914.

FRAZÃO, M.R. and FALCÃO, J.P., 2015. Genotypic diversity and pathogenic potential of Yersinia enterocolitica biotype 2 strains isolated in Brazil. Journal of Applied Microbiology, vol. 118, no. 4, pp. 1058-1067. http://dx.doi.org/10.1111/jam.12751. PMid:25639495.

FRAZÃO, M.R., ANDRADE, L.N., DARINI, A.L.C. and FALCÃO, J.P., 2017. Antimicrobial resistance and plasmid repliconsin Yersinia enterocolitic astrains isolated in Brazilin 30 years. The Brazilian Journal of Infectious Diseases, vol. 21, no. 4, pp. 477-480. http://dx.doi.org/10.1016/j.bjid.2017.04.006. PMid:28558260.

FREDRIKSSON-AHOMAA, M., CERNELA, N., HÄCHLER, H. and STEPHAN, R., 2010. Yersinia enterocolitica strains associated with human infections in Switzerland 2001-2010. European Journal of Clinical Microbiology \& Infectious Diseases, vol. 31, no. 7, pp. 1543-1550. http://dx.doi.org/10.1007/s10096011-1476-7. PMid:22071910.

FREDRIKSSON-AHOMAA, M., WACHECK, S., BONKE, R. and STEPHAN, R., 2011. Different enteropathogenic Yersinia strains found in wild boars and domestic pigs. Foodborne Pathogens and Disease, vol. 8, no. 6, pp. 733-737. http://dx.doi.org/10.1089/ fpd.2010.0711. PMid:21288132.

HADEF, K.Z., MEDJAHDI, K., BENAMAR, I. and BOUDJEMAA, B.M., 2015 [viewed 30 July 2020]. Safety characterization of Yersinia enterocolitica strains isolated from raw milk in Western Algeria. African Journal of Microbiological Research [online], vol. 10, no. 1, pp. 15-22. Available from: https://www.researchgate. net/profile/Khawla_Hadef/publication/293800570_Safety_ characterization of Yersinia enterocolitica strains isolated from raw milk in Western Algeria/links/5b1169450f7e $9 \mathrm{~b} 498101 \mathrm{c} 030 /$ Safety-characterization-of-Yersinia-enterocolitica-strains-isolatedfrom-raw-milk-in-Western-Algeria.pdf

HASSAN, A., USMAN, J., KALEEM, F., OMAIR, M., KHALID, A. and IQBAL, M., 2011. Evaluation of different detection meth $\neg$ ods of biofilm formation in the clinical isolates. The Brazilian Journal of Infectious Diseases, vol. 15, no. 4, pp. 305-311. http://dx.doi. org/10.1016/S1413-8670(11)70197-0. PMid:21860999. 
HAVENS, J.M., MOTOGOMERY, E., GREENSON, J.K., SCOTT, M.A. and LAMPS, L.W., 2003. Pathogenic Y. enterocolitica DNA is detected in gastrointestinal malakoplakia. Modern Pathology, vol. 16, pp. 1200A.

HÖFLING, J.F., ANIBAL, P.C., OBANDO-PEREDA, G.A., PEIXOTO, I.A., FURLETTI, V.F., FOGLIO, M.A. and GONÇALVES, R.B., 2010. Antimicrobial potential of some plant extracts against Candida species. Brazilian Journal of Biology = Revista Brasileira de Biologia, vol. 70, no. 4, pp. 1065. http:// dx.doi.org/10.1590/S1519-69842010000500022. PMid:21180915.

HOWARD, S.L., GAUNT, M.W., HINDS, J., WITNEY, A.A., STABLER, R. and WREN, B.W., 2006. Application of comparative phylogenomics to study the evolution of Yersinia enterocolitica and to identify genetic differences relating to pathogenicity. Journal of Bacteriology, vol. 188, no. 10, pp. 3645-3653. http:// dx.doi.org/10.1128/JB.188.10.3645-3653.2006. PMid:16672618.

IBRAHIM, A., LIESACK, W., GRIFFITHS, M.W. and ROBINSBROWNE, R.M., 1997. Development of a high specific assay for rapid identification of pathogenic strains of Yersinia enterocolitica based on PCR amplification of the Yersiniaheat-stable enterotoxin gene (yst). Journal of Clinical Microbiology, vol. 35, no. 6, pp. 1636-1638. http://dx.doi.org/10.1128/JCM.35.6.1636-1638.1997. PMid:9163505.

JEAN, S. and HSUEH, P.R., 2011. Current review of antimicrobial treatment of nosocomial pneumonia caused by multidrug-resistant pathogens. Journal Expert Opinion on Pharmacotherapy, vol. 12, no. 14, pp. 2145-2148. http://dx.doi.org/10.1517/14656566. 2011.599320. PMid:21895553.

JOHNSON, S.L., DALIGAULT, H.E., DAVENPORT, K.W., JAISSLE, J., FREY, K.G., LADNER, J.T., BROOMALL, S.M., BISHOP-LILLY, K.A., BRUCE, D.C., COYNE, S.R., GIBBONS, H.S., LO, C.C., MUNK, A.C., ROSENZWEIG, C.N., KOROLEVA, G.I., PALACIOS, G.F., REDDEN, C.L., XU, Y., MINOGUE, T.D. and CHAIN, P.S., 2015. Thirty-two complete genome assemblies of nine Yersinia Species, Including Y. pestis, Y. pseudotuberculosis, and Y. enterocolitica. Genome Announcements, vol. 3, no. 2, pp. e00148-e15. http://dx.doi. org/10.1128/genomeA.00148-15. PMid:25931590.

KOT, B., TRAFNY, E.A. and JAKUBCZAK, A., 2007. Application of multiplex PCR for monitoring colonization of pig tonsils by Yersinia enterocolitica, including biotype 1A, and Yersinia pseudotuberculosis. Journal of Food Protection, vol. 70, no. 5, pp. 1110-1115. http://dx.doi.org/10.4315/0362-028X-70.5.1110. PMid:17536668

LAGACÉ, L., PITRE, M., JACQUES, M. and ROY, D., 2004. Identification of the bacterial community of maple sap by using amplified ribosomal DNA (rDNA) restriction analysis and $\mathrm{rDNA}$ sequencing. Applied and Environmental Microbiology, vol. 70, no. 4, pp. 2052-2060. http://dx.doi.org/10.1128/AEM.70.4.20522060.2004. PMid:15066796.

LI, F. and FANNING, S., 2017. Antimicrobial resistance in foodrelated bacteria. In: J.J. JEN and J. CHEN, eds. Food safety in China: science and technology, management and regulation. Chichester: John Wiley \& Sons, pp. 163-184. http://dx.doi. org/10.1002/9781119238102.ch11.

LIANG, J., WANG, X., XIAO, Y., CUI, Z., XIA, S., HAO, Q., YANG, J., LUO, L., WANG, S., LI, K., YANG, H., GU, W., XU, J., KAN, B. and JING, H., 2012. Prevalence of Yersinia enterocolitica in pigs slaughtered in Chinese abattoirs. Applied and Environmental Microbiology, vol. 78, no. 8, pp. 2949-2956. http://dx.doi.org/10.1128/AEM.07893-11. PMid:22327599.
LOGUE, C.M., SHERIDAN, J.J., WAUTERS, G., MCDOWELL, D.A. and BLAIR, I.S., 1996. Yersinia spp. and numbers, with particular reference to $Y$. enterocolitica bio/serotypes, occurring on Irish meat and meat products, and the influence of alkali treatment on their isolation. International Journal of Food Microbiology, vol. 33, no. 2-3, pp. 257-274. http://dx.doi.org/10.1016/01681605(96)01164-6. PMid:8930710.

MASTRODONATO, A.C., FAVIER, G.I., LUCERO ESTRADA, C.S.M., VIDAL, R. and ESCUDERO, M.E., 2018. Bioserotypes, virulence genes, antimicrobial susceptibility and genomic diversity of Yersinia enterocolitica isolates from Argentina and Chile. Journal of Food Safety, vol. 38, no. 5, e12491. http://dx.doi. org/10.1111/jfs. 12491

MCDERMOTT, P.F., ZHAO, S., WAGNER, D.D., SIMJEE, S., WALKER, R.D. and WHITE, D.G., 2002. The food safety perspective of antibiotic resistance. Animal Biotechnology, vol. 13, no. 1, pp. 71-84. http://dx.doi.org/10.1081/ABIO-120005771. PMid:12212946.

MURROS-KONTIAINEN, A., FREDRIKSSON-AHOMAA, M., KORKEALA, H., JOHANSSON, P., RAHKILA, R. and BJÖRKROTH, J., 2011. Yersinia nurmii sp. Nov. International Journal of Systematic and Evolutionary Microbiology, vol. 61, no. 10, pp. 2368-2372. http://dx.doi.org/10.1099/ijs.0.024836-0. PMid:21037032.

MURROS, A., SADE, E., JOHANSSON, P., KORKEALA, H., FREDRIKSSON-AHOMAA, M. and BJORKROTH, J., 2016. Characterization of European Yersinia enterocolitica 1A strains using restriction fragment length polymorphism and multilocus sequence analysis. Letters in Applied Microbiology, vol. 63, no. 4, pp. 282-288. http://dx.doi.org/10.1111/lam.12626. PMid:27473388.

NAKAJIMA, H., INOUE, M., MORI, T., ITOH, K., ARAKAWA, E. and WATANABE, H., 1992. Detection and identification of Yersinia pseudotuberculosis and pathogenic Yersinia enterocolitica by an improved polymerase chain reaction method. Journal of Clinical Microbiology, vol. 30, no. 9, pp. 2484-2486. http:// dx.doi.org/10.1128/JCM.30.9.2484-2486.1992. PMid:1401022.

NANNI, F., PACIFICO, L., RENZI, A.M., VOLTERRA, L. and CHIESA, C., 1991. Urease-negative strains of Yersinia enterocolitica and related species isolated from human and nonhuman sources. Contributions to Microbiology and Immunology, vol. 12, pp. 44-49. PMid:1935112.

NEU, H.C., 1992. The crisis in antibiotic resistance. Science, vol. 257, no. 5073, pp. 1064-1073. http://dx.doi.org/10.1126/ science.257.5073.1064. PMid:1509257.

NEUBAUER, H., SPRAGUE, L.D., SCHOLZ, H. and HENSEL, A., 2001. The diagnostic of Yersinia enterocoliticainfections: a review on classical identification techniques and new molecular methods. Berliner und Munchener Tierarztliche Wochenschrift, vol. 114, no. 1-2, pp. 1-7. PMid:11225491.

ÖZDEMIR, F. and ARSLAN, S., 2015. Genotypic and phenotypic virulence characteristics and antimicrobial resistance of Yersinia spp. isolated from meat and milk products. Journal of Food Science, vol. 80, no. 6, pp. M1306-M1313. http://dx.doi.org/10.1111/17503841.12911. PMid:25969137.

PAIXÃO, R., MORENO, L.Z., SENA DE GOBBI, D.D., RAIMUNDO, D.C., FERREIRA, T.S., SPINDOLA, M.G., HOFER, E., FALAVINA DOS REIS, C.M., MATTÉ, M.H. and MICKE MORENO, A., 2013. Genotypic characterization of Yersinia enterocolitica biotype 4/O:3 isolates from pigs and slaughterhouses using SE-AFLP, ERIC-PCR, and PFGE. Journal of Pathogens, 
vol. 2013 , pp. 1-8. http://dx.doi.org/10.1155/2013/521510. PMid:23819054.

PENG, Z., ZOU, M., LI, M., LIU, D., GUAN, W., HAO, Q., XU, J., ZHANG, S., JING, H., LI, Y., LIU, X., YU, D., YAN, S., WANG, W. and LI, F., 2018. Prevalence, antimicrobial resistance and phylogenetic characterization of Yersinia enterocolitica in retail poultry meat and swine feces in parts of China. Food Control, vol. 93, pp. 121-128. http://dx.doi.org/10.1016/j.foodcont.2018.05.048.

PERUZY, M., MURRU, N., PERUGINI, A.G., CAPUANO, F., DELIBATO, E., MERCOGLIANO, R., KORKEALA, H. and PROROGA, Y.T.R., 2017. Evaluation of virulence genes in Yersinia enterocolitica strains using SYBR Green real-time PCR. Food Microbiology, vol. 65, pp. 231-235. http://dx.doi. org/10.1016/j.fm.2017.03.004. PMid:28400007.

PIENIZ, S., RODRIGUES, D.F., ARNDT, R.M., MELLO, J.F., RODRIGUES, K.L., ANDREAZZA, R., CAMARGO, F.A.O. and BRANDELLI, A., 2019. Molecular identification and microbiological evaluation of isolates from equipments and food contact surfaces in a hospital Food and Nutrition Unit. Brazilian Journal of Biology $=$ Revista Brasileira de Biologia, vol. 79, no. 2, pp. 191. http://dx.doi.org/10.1590/1519-6984.175350. PMid:30365634.

PLATT-SAMORAJ, A., UGORSKI, M., SZWEDA, W., SZCZERBA-TUREK, A., WOJCIECH, K. and PROCAJŁO, Z., 2006. Analysis of the presence of ail, ystA and $y s t B$ genes in Yersinia enterocoliticastrains isolated from aborting sows and aborted fetuses. Journal of Veterinary Medicine, Series B, vol. 53, no. 7, pp. 341-346. http://dx.doi.org/10.1111/j.14390450.2006.00969.x.

RAMÍREZ, E., VÁZQUEZ-SALINAS, C., RODAS-SUÁREZ, O.R. and PEDROCHE, F.F., 2000. Isolation of Yersinia from raw meat (pork and chicken) and precooked meat (porcine tongues and sausages) collected from commercial establishments in Mexico City. Journal of Food Protection, vol. 63, no. 4, pp. 542-544. http://dx.doi.org/10.4315/0362-028X-63.4.542. PMid:10772223.

RASMUSSEN, H.N., RASMUSSEN, O.F., ANDERSEN, J.K. and OLSEN, J.E., 1994. Specific detection of pathogenic Yersinia enterocolitica by two-step PCR using hot-start and DMSO. Molecular and Cellular Probes, vol. 8, no. 2, pp. 99-108. http:// dx.doi.org/10.1006/mcpr.1994.1014. PMid:7935518.

RAY, B., 2004. Fundamental food microbiology. 3rd ed. Florida: CRC Press.

ROZWANDOWICZ, M., BROUWER, M.S.M., FISCHER, J., WAGENAAR, J.A., GONZALEZ-ZORN, B., GUERRA, B., MEVIUS, D.J. and HORDIJK, J., 2018. Plasmids carrying antimicrobial resistance genes in Enterobacteriaceae. The Journal of Antimicrobial Chemotherapy, vol. 73, no. 5, pp. 1121-1137. http://dx.doi.org/10.1093/jac/dkx488. PMid:29370371.

SACCHINI, L., GAROFOLO, G., DI SERAFINO, G., MAROTTA, F., RICCI, L., DI DONATO, G., MIRACCO, M.G., PERLETTA, F. and DI GIANNATALE, E., 2018. The prevalence, characterisation, and antimicrobial resistance of Yersinia enterocolitica in pigs from Central Italy. Veterinaria Italiana, vol. 54, no. 2, pp. 115123. PMid:30019328.

SCHMIDT, T.M. and RELMAN, D.A., 1994. Phylogenetic identification of uncultured pathogens using ribosomal RNA sequences. Methods in Enzymology, vol. 235, pp. 205-222. http:// dx.doi.org/10.1016/0076-6879(94)35142-2. PMid:7520119.

SHABANA, S.M., KHALIL, S. and HEGAZY, A.E.H., 2015. Molecular characterization of Yersinia enterocolitica isolated from chicken meat samples. Alexandria Journal of Veterinary Sciences, vol. 46, no. 1, pp. 124-129. http://dx.doi.org/10.5455/ ajvs. 184190 .

SIHVONEN, L.M., JALKANEN, K., HUOVINEN, E., TOIVONEN, S., CORANDER, J., KUUSI, M., SKURNIK, M., SIITONEN, A. and HAUKKA, K., 2012. Clinical isolates of Yersinia enterocolitica Biotype 1A represent two phylogenetic lineages with differing pathogenicity-related properties. BMC Microbiology, vol. 12, pp. 208. http://dx.doi.org/10.1186/1471-2180-12-208. PMid:22985268.

SILVA, J., LEITE, D., FERNANDES, M., MENA, C., GIBBS, P.A. and TEIXEIRA, P., 2011. Campylobacter spp. as a food borne pathogen: a review. Frontiers in Microbiology, vol. 2, pp. 200. http://dx.doi.org/10.3389/fmicb.2011.00200. PMid:21991264.

SIRIKEN, B., 2004 [viewed 30 July 2020]. The presence of Yersinia enterocoliticaand other Yersinia species in ground beef in Aydın, Turkey. Turkish Journal of Veterinary and Animal Sciences [online], vol. 28, pp. 489-495. Available from: http://journals. tubitak.gov.tr/veterinary/issues/vet-04-28-3/vet-28-3-5-0209-1.pdf

TADESSE, D.A., BAHNSON, P.B., FUNK, J.A., MORROW, W.E., ABLEY, M.J., PONTE, V.A., THAKUR, S., WITTUM, T., DEGRAVES, F.J., RAJALA-SCHULTZ, P.J. and GEBREYES, W.A., 2013. Yersinia enterocolitica of porcine origin: carriage of virulence genes and genotypic diversity. Foodborne Pathogens and Disease, vol. 10, no. 1, pp. 80-86. http://dx.doi.org/10.1089/ fpd.2011.1120. PMid:23320426.

TAMURA, K., STECHER, G., PETERSON, D., FILIPSKI, A. and KUMAR, S., 2013. MEGA6: molecular evolutionary genetics analysis version 6.0. Molecular Biology and Evolution, vol. 30, no. 12, pp. 2725-2729. http://dx.doi.org/10.1093/molbev/mst197. PMid:24132122.

THOERNER, P., BIN KINGOMBE, C.I., BÖGLI-STUBER, K., BISSIG-CHOISAT, B., WASSENAAR, T.M., FREY, J. and JEMMI, T., 2003. PCR detection of virulence genes in Yersinia enterocolitica and Yersinia pseudotuberculosis and investigation of virulence gene distribution. Applied and Environmental Microbiology, vol. 69, no. 3, pp. 1810-1816. http://dx.doi. org/10.1128/AEM.69.3.1810-1816.2003. PMid:12620874.

THOMPSON, J.D., HIGGINS, D.G. and GIBSON, T.J., 1994. CLUSTAL W: improving the sensitivity of progressive multiple sequence alignment through sequence weighting, position-specific gap penalties and weight matrix choice. Nucleic Acids Research, vol. 22, no. 22, pp. 4673-4680. http://dx.doi.org/10.1093/ nar/22.22.4673. PMid:7984417.

THONG, K.L., TAN, L.K. and OOI, P.T., 2018. Genetic diversity, virulotyping and antimicrobial resistance susceptibility of Yersinia enterocolitica isolated from pigs and porcine products in Malaysia. Science of Food and Agriculture, vol. 98, no. 1, pp. 87-95. http:// dx.doi.org/10.1002/jsfa.8442. PMid:28542807.

TSUBAKISHITA, S., KUWAHARA-ARAI, K., BABA, T. and HIRAMATSU, K., 2010. Staphylococcal cassette chromosome mec-like element in Macrococcus caseolyticus. Antimicrobial Agents and Chemotherapy, vol. 54, no. 4, pp. 1469-1475. http:// dx.doi.org/10.1128/AAC.00575-09. PMid:20086147.

WANG, X., CUI, Z., JIN, D., TANG, L., XIA, S., WANG, H., XIAO, Y., QIU, H., HAO, Q., KAN, B., XU, J. and JING, H., 2009. Distribution of pathogenic Yersinia enterocolitica in China. European Journal of Clinical Microbiology \& Infectious Diseases, vol. 28, no. 10, pp. 1237-1244. http://dx.doi.org/10.1007/s10096009-0773-x. PMid:19575249. 
WESLEY, I.V., BHADURI, S. and BUSH, E., 2008. Prevalence of Yersinia enterocolitica in market weight hogs in the United States. Journal of Food Protection, vol. 71, no. 6, pp. 1162-1168. http://dx.doi.org/10.4315/0362-028X-71.6.1162. PMid:18592741.

WOESE, C.R., 1987. Bacterial evolution. Microbiological Reviews, vol. 51, no. 2, pp. 221-271. http://dx.doi.org/10.1128/ MMBR.51.2.221-271.1987. PMid:2439888.

WORTBERG, F., NARDY, E., CONTZEN, M. and RAU, J., 2012. Identification of Yersinia ruckeri from diseased salmonid fish by Fourier transform infrared spectroscopy. Journal of Fish Diseases, vol. 35, no. 1, pp. 1-10. http://dx.doi.org/10.1111/j.13652761.2011.01317.x. PMid:22103737.

YE, Q., WU, Q., HU, H., ZHANG, J. and HUANG, H., 2015. Prevalence, antimicrobial resistance and genetic diversity of Yersinia enterocolitica isolated from retail frozen foods in China. FEMS Microbiology Letters, vol. 362, no. 24, pp. fnv197. http:// dx.doi.org/10.1093/femsle/fnv197. PMid:26472688.

YE, Q., WU, Q., HU, H., ZHANG, J. and HUANG, H., 2016. Prevalence and characterization of Yersinia enterocolitica isolated from retail foods in China. Food Control, vol. 61, pp. 20-27. http://dx.doi.org/10.1016/j.foodcont.2015.09.016.
YOUNIS, G., MADY, M. and AWAD, A., 2019. Yersinia enterocolitica: Prevalence, virulence, and antimicrobial resistance from retail and processed meat in Egypt. Veterinary World, vol. 12, no. 7, pp. 1078-1084. http://dx.doi.org/10.14202/vetworld.2019.1078-1084. PMid:31528036.

ZADERNOWSKA, A. and CHAJĘCKA-WIERZCHOWSKA, W., 2016. Prevalence, biofilm formation and virulence markers of Salmonella sp. and Yersinia enterocolitica in food of animal origin in Poland. Lebensmittel-Wissenschaft + Technologie, vol. 75, pp. 552-556. http://dx.doi.org/10.1016/j. lwt.2016.10.007.

ZEINALI, T., JAMSHIDI, A., RAD, M. and BASSAMI, M., 2015. A comparison analysis of Listeria monocytogenes isolates recovered from chicken carcasses and human by using RAPD PCR. International Journal of Clinical and Experimental Medicine, vol. 8, no. 6, pp. 10152-10157. PMid:26309714.

ZHENG, H., SUN, Y., MAO, Z. and JIANG, B., 2008. Investigation of virulence genes in clinical isolates of Yersinia enterocolitica. FEMS Immunology and Medical Microbiology, vol. 53, no. 3, pp. 368-374. http://dx.doi.org/10.1111/j.1574-695X.2008.00436.x. PMid:18557936. 